\title{
Physico-Functional and Starch Pasting Properties of Cassava (Manihot Esculenta Cruntz) Flours as Influenced by Processing Technique and Varietal Variations
}

\author{
E. O. Afoakwa ${ }^{1,7}$, G. O. Sampson ${ }^{2 *}$, D. Nyirenda ${ }^{3}$, C. N. Mwansa ${ }^{4}$, L. Brimer ${ }^{5}$, and L. Chiwona-Karltun ${ }^{6}$ \\ ${ }^{1}$ Department of Nutrition \& Food Science, University of Ghana \\ Legon-Accra, Ghana
}

${ }^{2}$ Faculty of Vocational Education, Akenten Appiah-Menka University of Skills Training and Entrepreneurial Development Kumasi, Ghana

${ }^{3}$ Department of Animal Science, University of Zambia

Lusaka, Zambia

${ }^{4}$ Department of Food Science and Technology, University of Zambia

Lusaka, Zambia

${ }^{5}$ Department of Veterinary Disease Biology, Chemical Food Safety and Toxicology, University of Copenhagen

Copenhagen, Denmark

${ }^{6}$ Department of Urban \& Rural Development, Swedish University of Agricultural Sciences (SLU)

Uppsala, Sweden

${ }^{7}$ Ghana Communication Technology University

Accra, Ghana

*Corresponding author: gosampson@uew.edu.gh

\begin{abstract}
This study investigated effects of processing technique and varietal variations on the physicofunctional, starch pasting and viscoelastic properties of cassava (Manihot Esculenta Crantz) flours using a 3x6 factorial experimental approach. Samples were evaluated for their non-volatile acidity, $\mathrm{pH}$, swelling power, solubility water absorption capacity $\left(27^{\circ} \mathrm{C}\right.$ and $\left.70^{\circ} \mathrm{C}\right)$, colour and starch pasting characteristics of the cassava flours using standard methods. Grating and soaking of the cassava tubers significantly $(p<0.05)$ reduced the $p H$ of all the varieties with concomitant increases in non-volatile acidity. Grating and soaking significantly $(p<0.05)$ reduced the swelling power, solubility and water absorption capacity of the flours. Soaked Chila B flour recorded the highest pasting temperature of $66.9^{\circ} \mathrm{C}$ whiles soaked Mweulu flour recorded the highest peak viscosity $(684 \mathrm{BU})$, viscosity at $95^{\circ} \mathrm{C}$ $(683 \mathrm{BU})$ and viscosity at $95^{\circ} \mathrm{C}$-hold $(359 \mathrm{BU})$, suggesting that the flours from the different cassava varieties could be targeted for different food and industrial products.
\end{abstract}

Keywords--- Cassava, starch, functional properties, viscoelastic properties, pasting characteristics

\section{INTRODUCTION}

Cassava (Manihot esculenta Crantz) is among the most important root crops in the world and research shows that it provides food for about one billion people (Bokanga 2001; FAO 2008). It is also reported to contribute significantly to the economy of most tropical countries (Bokanga 2001; Kawano 2003; Amani et al. 2005) through processing into various products (Abu et al. 2006; Assanvo 2008; Apea-Bah et al. 2009). Besides providing food for about one billion people with the majority within tropical countries, cassava is a very useful raw material with a wide range of applications in both the food and non-food industries. These industrial applications of cassava depend on the functional properties of the cassava which vary considerably from one variety to another (Yuan et al. 2007), and environmental conditions (Shujun et al. 2006; Riley et al. 2006).

Physico-functional properties of cassava are among the most important parameters used to ascertain the suitability of flours and starch for certain end uses. It helps in the selection of a variety for use in the industry as a thickener, binder or for any other food and industrial use (Afoakwa et al. 2012). Functional properties are those properties that provide information on how food ingredients behave in a food system during processing. These properties include swelling power, solubility, water absorption capacity, swelling volume, bulk density, and gelation properties. These properties control the sensory attributes and stability of processed starch products. Several factors have been reported to influence the degree and kind of functional properties of foods and these include the starch 
composition and concentration, ratio of amylose to amylopectin, characteristics of each fraction in terms of molecular weight/distribution, degree/length of branching and conformation of starch (Mégnanou et al. 2009).

Viscoelastic properties have been used to determine the gelatinization of suspensions from a variety of cassava and yam starches as well as their pasting characteristics during heating and subsequent cooling (Afoakwa and Sefa-Dedeh 2002; Maziya-Dixon et al. 2007; Afoakwa et al. 2010a). One of the major processing indices of cassava flour is its ability to gelatinize and form thick pastes for human consumption and the gelatinization process is a property of the starch granule found in cereals and tuber crops (Iwe et al 1999). Pasting characteristics of starches are essential in determining the industrial applications of the starches. For use as thickeners, Afoakwa et al. (2012) reported that the paste formed should not retrograde and should also have high paste stability, when cold or hot. Cassava flour can also be used in the bakery industry for bread and pastries such as cakes, biscuits, etc., as substitutes of wheat flour. Again, attaining gelatinization at a lower temperature has been reported to improve bread-making quality (Defloor et al. 1994) whiles high peak viscosity and stability (or low breakdown viscosity) of cassava flour gives acceptable bread (Adeyemi and Omolayo 1984). A low setback value indicates that flour gives a non-cohesive paste (Kim et al. 1995). This means that such starches cannot be used for products in which starch stability is required at low temperatures such as products that require refrigeration (Aryee et al. 2006).

There are three common methods of processing cassava in south-eastern Africa and these include soaking (soaking is traditional and still used for taste), chipping and grating. The choice of the method used depends on the desired end product. The soaking method is used if the desired product is cassava meal (for preparation of staple meal, nshima) whiles the chipping and grating methods are mainly used for the production of cassava flour and are more modern. Processing of cassava facilitate preservation, improve palatability and product quality as well as leads to the production of diversified food products. Again, both varietal differences and processes influence the production of diversified food products due to inherent characteristics such as starch content, sugar content. Some of the cassava varieties grown extensively across south-eastern Africa include Chila A, Chila B, Mweulu, Bangweulu, Tanganyika and Kampolombo. The extent to which processing techniques commonly used in south eastern Africa (soaking, chipping and grating) would influence the physico-functional and viscoelastic properties of these cassava varieties remains unclear. This work investigated the effects of processing technique (chipping, grating and soaking) and varietal variations on the physico-functional, starch pasting and viscoelastic properties of flours from different cassava (Manihot Esculenta Crantz) varieties from south-eastern African region.

\section{Cassava samples}

\section{MATERIALS AND METHODS}

Six varieties of cassava (Chila A, Chila B, Mweulu, Bangweulu, Tanganyika and Kampolombo) were obtained from the experimental fields of the Agricultural Research Institute of Zambia, Lusaka, Zambia and used for the study.

\section{Sample Preparation}

The samples were harvested from the experimental fields of the Agricultural Research Institute of Zambia and transported immediately to the laboratory where they were processed using three common processing techniques (chipping, grating and soaking). Preliminary treatments in the processing of cassava in the three methods included trimming of the undesired parts of cassava tubers, washing and peeling. The tubers were then soaked, chipped or grated. Soaking was done in plastic drums for 48 hours after which the cassava tubers were dried. The drying method was the sun drying. The dried cassava tubers, chips or grates were then milled into flour and used for analyses.

\section{Analytical methods}

pH

Ten grams of the dried cassava flour samples were mixed with $100 \mathrm{ml}$ distilled water. The mixture was allowed to stand for 15 min, shaken at 5-min intervals and filtered using Whatman No. 4 filter paper. The $\mathrm{pH}$ of the filtrate was then measured using a $\mathrm{pH}$ meter (Taklon, Model H M 305, Tokyo, Japan).

\section{Titratable acidity}

Ten grams of the dried cassava flour samples were weighed into a clean beaker and mixed with $100 \mathrm{ml}$ distilled water. The mixture was filtered using a Whatman No. 4 filter paper. Ten milliliters of the filtrate were titrated against $0.1 \mathrm{M} \mathrm{NaOH}$ using $1 \%$ phenolphthalein as indicator. Acidity was calculated as grams of lactic acid per $100 \mathrm{~g}$ sample.

\section{Colour determination}

Colour of the samples were determined using a Hunter Lab Colour Difference meter (CDM) model CR-300 (Minolta camera co. Ltd; Tokyo, Japan) using a white porcelain plate with $\mathrm{L}=98.34, \mathrm{a}=-0.21$ and $\mathrm{b}=0.19$ as reference. The results obtained were expressed in Hunter $L^{*}, a^{*}$ and $b^{*}$ values. $L^{*}$ represent lightness (with $0=$ darkness/blackness to $100=$ perfect/brightness); $a^{*}$ corresponds to the extent of green colour (in the range from negative $=$ green to positive $=$ redness); $b^{*}$ represents blue in the range from negative $=$ blue to positive $=$ yellow. Triplicate readings were made and the average taken .

\section{Determination of swelling power and solubility}

Swelling power and solubility determinations were based on modification of the method of (Hashim et al. 1992). One gram of flour was weighed into a $50 \mathrm{ml}$ graduated centrifuge tube. Distilled water was added to give a total volume of $40 \mathrm{ml}$. The suspension was stirred sufficiently and heated at $85^{\circ} \mathrm{C}$ in a water bath for $30 \mathrm{~min}$ with constant stirring. The tubes were cooled to room temperature and centrifuged for $15 \mathrm{~min}$ at $2200 \mathrm{rpm}$. The solubility was determined by evaporating the supernatant and weighing the residue. The swelling power was obtained by directly reading the volume of the swollen sediment in the tube. The $\%$ solubility and swelling power were calculated and their mean values reported. 


\section{Determination of water absorption capacity}

Water absorption capacity (WAC) was determined by the method of (Hashim et al. 1992). An aqueous suspension was made by dissolving $2 \mathrm{~g}$ of cassava flour in $40 \mathrm{ml}$ of water. The suspension was agitated for $1 \mathrm{~h}$ on Griffin flask shaker (Griffin and George Ltd. Birmingham, UK) after which it was centrifuged for $10 \mathrm{~min}$ at $2200 \mathrm{rpm}$. The free water (supernatant) was decanted from the wet cassava flour, and the increase in weight noted by weighing the sediment. The water absorbed was calculated and the water absorption capacity expressed as a percentage of the initial sample weight. The analysis were conducted in triplicates and mean value reported.

\section{Determination of viscoelastic properties and starch pasting characteristics}

The viscoelastic properties as well as the starch pasting characteristics were determined by using a Brabender ViscoAmylograph (Model No. 802525, Duisburg, Germany). An aqueous suspension of $40 \mathrm{~g}$ flour (dry basis) in $420 \mathrm{ml}$ of distilled water was heated from 50 to $95^{\circ} \mathrm{C}$ at a rate of $1.5^{\circ} \mathrm{C} / \mathrm{min}$ by means of a thermoregulator. At $95^{\circ} \mathrm{C}$ the sample was held constant for 20 min (first holding period) while being stirred continuously. The paste was cooled to $50^{\circ} \mathrm{C}$ at $1.5^{\circ} \mathrm{C} / \mathrm{min}$ and held at that temperature for 15 min (second holding period). Pasting temperature, peak (maximum) viscosity at each stage and the peak temperature were taken from the amylograph curves. From these measurements the setback viscosity, retrogradation tendency and paste stability at 95 and $50{ }^{\circ} \mathrm{C}$ were computed (Champange et al. 1999).

\section{Statistical analysis}

Statistical analysis and graphical presentation were done using Minitab (version 14) and Microsoft Excel (2007 version) respectively. Analysis of variance for the cassava varieties was conducted at a level of significance of $p<0.05$. Least significant difference (LSD) was used to separate and compare the means, and significance was accepted at $5 \%$ level ( $\mathrm{p}<0.05$ ). All analytical determinations of data were performed in triplicate and mean values along with standard deviation were reported.

\section{RESULTS AND DISCUSSION}

\section{pH and titratable acidity of cassava varieties}

Table 1 gives the $\mathrm{pH}$ and titratable acidity of the various cassava varieties for the various processing methods. Results showed that grating and soaking of the cassava tubers significantly $(\mathrm{p}<0.05)$ reduced the $\mathrm{pH}$ of all the varieties with the exception of Kampolombo. The pH of the flour of Chila A chips reduced from 6.06 to 5.64 (grated Chila A) and 5.50 (soaked Chila A). Similar trend of decrease was observed for all the other varieties except for Kampolombo. Titratable acidity of the cassava varieties on the other hand increased significantly $(\mathrm{p}<0.05)$ for both the grated and soaked cassava samples compared to the chips. Titratable acidity of Chila A chips increased from 0.0179 to 0.0241 (grated Chila A) and $0.0259 \mathrm{~g}$ lactic acid/100g sample (soaked Chila A). Similar trend of decrease was observed for all the other varieties except for Kampolombo which decreased slightly. The decrease in $\mathrm{pH}$ with consequential increase in titratable acidity was more profound in the samples that were soaked. This is because during the soaking process, some degree of lactic acid fermentation takes place where activity of the lactic acid bacteria leads to the production of organic acids and other metabolites causing souring or acidification of the product (Afoakwa et al. 2010b). Acid production has been reported to be responsible for product stability, flavour development and cyanide elimination (Okigbo 1980; Lei et al. 1999). Sefa-Dedeh et al. (2004) reported that lactic acid fermentation exhibits antimicrobial effects on pathogenic microorganisms due to the presence of acid.

\section{Colour of cassava varieties}

Colour is one of the most important attributes of food, both for its aesthetic value and for quality judgment (Vamos-Vigyazo 1981). It affects our overall judgment on the worth of food from both an aesthetic and safety point of view (Clydesdale 1984). It plays an important role in taste thresholds, flavor identification, food preferences, pleasantness, acceptability and ultimately food choice. However its role is elusive and difficult to quantify (Clydesdale 1984). Colour of cassava is an important criterion for quality, especially for use in the food industries. The cassava or cassava flour should be clear, have a good white colour, and free from any offcolour for better acceptability. The results from the colour determination given in Table 2 indicate that grating and soaking caused a significant $(\mathrm{p}<0.05)$ increase in the $\mathrm{L}^{*}$-values of the cassava flours compared to the cassava chip flours. The $\mathrm{L}^{*}$-value increased from 68.36 for Mweulu chips to 71.21 (grated Mweulu) and 71.51 (soaked Mweulu). However, soaked Chila B and Bangweulu flour samples had a lighter colour ( $\mathrm{L}^{*}$-values less) than their respective flour made from the chips. Soaked Kampolombo had the highest $\mathrm{L}^{*}$ value of 78.40 suggesting that the soaked Kampolombo cassava sample was whiter than the rest of the samples. 
Table 1: Physico-chemical and functional properties of cassava flour

\begin{tabular}{|c|c|c|c|c|c|c|c|}
\hline $\begin{array}{l}\text { Processing } \\
\text { method }\end{array}$ & Variety & pH & $\begin{array}{c}\text { Titratable } \\
\text { acidity }\end{array}$ & $\begin{array}{c}\text { Water } \\
\text { absorption } \\
\text { capacity at } \\
27^{\circ} \mathrm{C}(\%)\end{array}$ & $\begin{array}{c}\text { Water } \\
\text { absorption } \\
\text { capacity at } \\
7^{\circ} \mathrm{C}(\%)\end{array}$ & $\begin{array}{c}\text { Solubility } \\
(\%)\end{array}$ & $\begin{array}{c}\text { Swelling } \\
\text { power } \\
(\%)\end{array}$ \\
\hline \multirow[t]{6}{*}{ Chips } & Chila A & $6.06 \pm 0.01$ & $0.0179 \pm 0.0007$ & $178.64 \pm 31.70$ & $224.39 \pm 14.55$ & $68.01 \pm 1.93$ & $14.14 \pm 0.59$ \\
\hline & Chila B & $5.84 \pm 0.01$ & $0.0198 \pm 0.0004$ & $230.55 \pm 35.76$ & $231.21 \pm 12.31$ & $61.42 \pm 14.45$ & $15.24 \pm 2.31$ \\
\hline & Mweulu & $6.09 \pm 0.02$ & $0.0161 \pm 0.0034$ & $156.66 \pm 11.74$ & $233.40 \pm 32.40$ & $72.50 \pm 3.09$ & $14.08 \pm 0.02$ \\
\hline & Bangweulu & $6.38 \pm 0.02$ & $0.0206 \pm 0.0013$ & $172.44 \pm 24.92$ & $181.79 \pm 1.55$ & $74.55 \pm 13.65$ & $21.08 \pm 1.00$ \\
\hline & Tanganyika & $6.23 \pm 0.04$ & $0.0188 \pm 0.0013$ & $159.82 \pm 10.58$ & $185.32 \pm 23.12$ & $42.77 \pm 5.47$ & $10.49 \pm 2.14$ \\
\hline & Kampolombo & $5.39 \pm 0.05$ & $0.0215 \pm 0.0075$ & $174.42 \pm 3.59$ & $234.31 \pm 9.44$ & $69.19 \pm 12.71$ & $16.36 \pm 2.54$ \\
\hline \multirow[t]{6}{*}{ Grating } & Chila A & $5.64 \pm 0.01$ & $0.0241 \pm 0.0013$ & $129.43 \pm 9.43$ & $155.06 \pm 30.36$ & $15.67 \pm 1.10$ & $11.73 \pm 0.61$ \\
\hline & Chila B & $5.58 \pm 0.03$ & $0.0689 \pm 0.0809$ & $216.21 \pm 4.07$ & $242.14 \pm 0.19$ & $22.55 \pm 3.25$ & $12.22 \pm 0.48$ \\
\hline & Mweulu & $5.70 \pm 0.05$ & $0.0259 \pm 0.0013$ & $197.20 \pm 17.15$ & $232.50 \pm 16.12$ & $30.55 \pm 5.56$ & $12.15 \pm 0.65$ \\
\hline & Bangweulu & $5.84 \pm 0.03$ & $0.0255 \pm 0.0006$ & $160.45 \pm 1.52$ & $164.39 \pm 11.48$ & $15.57 \pm 0.43$ & $10.20 \pm 0.23$ \\
\hline & Tanganyika & $5.62 \pm 0.05$ & $0.0134 \pm 0.0013$ & $168.38 \pm 14.86$ & $169.94 \pm 7.74$ & $48.46 \pm 8.35$ & $12.79 \pm 1.23$ \\
\hline & Kampolombo & $5.42 \pm 0.07$ & $0.0214 \pm 0.0034$ & $156.07 \pm 3.29$ & $158.19 \pm 13.37$ & $12.63 \pm 1.80$ & $10.26 \pm 0.14$ \\
\hline \multirow[t]{6}{*}{ Soaking } & Chila A & $5.50 \pm 0.02$ & $0.0259 \pm 0.0013$ & $125.22 \pm 10.51$ & $180.65 \pm 73.19$ & $17.47 \pm 6.89$ & $13.96 \pm 3.29$ \\
\hline & Chila B & $5.53 \pm 0.03$ & $0.0603 \pm 0.0006$ & $142.64 \pm 3.73$ & $150.21 \pm 5.82$ & $32.55 \pm 9.35$ & $14.99 \pm 3.15$ \\
\hline & Mweulu & $5.76 \pm 0.07$ & $0.0375 \pm 0.0025$ & $191.32 \pm 7.14$ & $220.91 \pm 42.92$ & $12.29 \pm 5.49$ & $11.75 \pm 4.29$ \\
\hline & Bangweulu & $6.10 \pm 0.03$ & $0.0183 \pm 0.0013$ & $186.44 \pm 2.21$ & $197.49 \pm 4.65$ & $49.38 \pm 1.21$ & $16.57 \pm 2.69$ \\
\hline & Tanganyika & $5.96 \pm 0.07$ & $0.0241 \pm 0.0006$ & $131.24 \pm 3.58$ & $160.71 \pm 56.40$ & $8.20 \pm 3.54$ & $11.44 \pm 2.07$ \\
\hline & Kampolombo & $5.85 \pm 0.08$ & $0.0224 \pm 0.0012$ & $210.74 \pm 0.37$ & $221.15 \pm 15.63$ & $39.85 \pm 5.76$ & $18.54 \pm 1.38$ \\
\hline
\end{tabular}

Table 2: Colour of cassava flour as affected by processing

\begin{tabular}{lllll}
\hline $\begin{array}{l}\text { Processing } \\
\text { method }\end{array}$ & Variety & L*$^{*}$-value & $\mathbf{a}^{*}$-value & b $^{*}$-value \\
\hline Chips & Chila $\boldsymbol{A}$ & $70.12 \pm 0.03$ & $-1.40 \pm 0.02$ & $+9.53 \pm 0.01$ \\
& Chila B & $68.81 \pm 0.02$ & $-1.39 \pm 0.04$ & $+9.92 \pm 0.04$ \\
& Mweulu & $68.36 \pm 0.00$ & $-1.65 \pm 0.01$ & $+8.23 \pm 0.02$ \\
& Bangweulu & $70.58 \pm 0.01$ & $-1.75 \pm 0.03$ & $+7.99 \pm 0.01$ \\
& Tanganyika & $69.58 \pm 0.03$ & $-1.17 \pm 0.01$ & $+7.12 \pm 0.04$ \\
& Kampolombo & $68.66 \pm 0.02$ & $-1.71 \pm 0.01$ & $+9.92 \pm 0.01$ \\
& & & & \\
Grating & Chila A & $70.37 \pm 0.52$ & $-1.21 \pm 0.01$ & $+6.42 \pm 0.05$ \\
& Chila B & $69.85 \pm 0.54$ & $-1.09 \pm 0.04$ & $+8.01 \pm 0.10$ \\
& Mweulu & $71.21 \pm 0.19$ & $-1.34 \pm 0.02$ & $+8.37 \pm 0.07$ \\
& Bangweulu & $75.72 \pm 0.46$ & $-1.18 \pm 0.01$ & $+9.22 \pm 0.07$ \\
& Tanganyika & $71.75 \pm 0.01$ & $-1.10 \pm 0.01$ & $+7.65 \pm 0.00$ \\
& Kampolombo & $77.54 \pm 1.07$ & $-1.03 \pm 0.01$ & $+8.76 \pm 0.11$ \\
& & & & \\
& Chila A & $71.04 \pm 0.01$ & $-0.93 \pm 0.00$ & $+8.46 \pm 0.03$ \\
& Chila B & $68.12 \pm 0.18$ & $-0.92 \pm 0.05$ & $+7.51 \pm 0.05$ \\
& Mweulu & $71.51 \pm 0.08$ & $-0.88 \pm 0.03$ & $+8.28 \pm 0.04$ \\
& Bangweulu & $68.48 \pm 0.62$ & $-0.83 \pm 0.03$ & $+6.69 \pm 0.05$ \\
& Tanganyika & $72.49 \pm 0.86$ & $-0.93 \pm 0.01$ & $+7.25 \pm 0.10$ \\
& Kampolombo & $78.40 \pm 0.32$ & $-0.74 \pm 0.00$ & $+8.13 \pm 0.01$ \\
\hline & & & &
\end{tabular}




\section{Functional properties of cassava varieties Swelling power of cassava varieties}

Swelling power is the maximum increase in volume and weight which starch undergoes when allowed to swell freely in water (Afoakwa et al. 2012). The swelling power of starch depends on the capacity of starch molecules to hold water through hydrogen bonding. Thus, it gives an idea of how much water is able to enter into the amyloplast of starch granules which useful in predicting the behaviour of the starch in the food systems. The swelling power of the various cassava varieties processed using the three processing techniques are presented in Table 1. Results showed that grating cassava as well as soaking cassava tubers for 48 hours significantly $(\mathrm{p}<0.05)$ reduced the swelling power of the cassava flour. Swelling power decreased from $14.14 \%$ for the flour of Chila A chips to $11.73 \%$ (grated Chila A) and $13.96 \%$ (soaked Chila A). Similar trend of decrease was observed for all the other cassava varieties. Grated and soaked Tanganyika however had high swelling power compared to Tanganyika chip flour. Soaked Kampolombo also had high swelling power compared to the chips and the grated Kampolombo. Bangweulu chip flour however, recorded the highest swelling power of $21.08 \%$ among all the varieties studied and processing method used.

Swelling power of the samples reflects the extent of associative forces within the starch, therefore, the higher the swelling power, the higher the associative forces. The differences in the swelling power of the cassava varieties for the various processing methods indicate structural differences among starches of the various cassava varieties. Soaking of the cassava tubers involves some degree of fermentation where microorganisms break down the starch in the cassava to reducing sugars (Afoakwa et al. 2010b). This might probably lead to the modification of the starch structure and content in the cassava, thus influencing the swelling power. Moorthy and Ramanujam (1986) reported that swelling power of cassava flour is dependent on the variety, environmental factors, age of the crop as well as method used to process the cassava. Gujska et al. (1994) and Tang et al. (2005) observed swelling power to be influenced by a strong bonded micellar network, amylopectin molecular structure and amylose content. Work by Sasaki and Matsuki (1998) and Srichuwong et al. (2005) found swelling power to increase with increasing long chains of amylopectin and decreasing amylose content.

\section{Solubility of cassava varieties}

Solubility reflects the extent of intermolecular cross bonding within the starch granule (Hari et al. 1989). Cassava starch is reported to have a higher solubility compared to other tuber crops, and the higher solubility can be attributed partly to the high swelling it undergoes during gelatinization (Moorthy 1985). Solubility of the cassava varieties varied from one variety to the other and for one processing method to the other. It ranged from $8.20 \%$ to $74.55 \%$ for all the cassava varieties (Table 1). Results also showed that grating and soaking cassava significantly $(\mathrm{p}<0.05)$ reduced the solubility of the samples. Bangweulu chips recorded the highest solubility of $74.55 \%$ among all the varieties studied and processing method used. High solubility means that the crystallinity and spatial structure of the starch polymer has been reduced. This means more sites of H-bonding available for interaction with water molecules. The higher the solubility value the more effective the starch would dissolve in adhesive mixture and enhance its action. Aryee et al. (2006) also reported that low swelling accompanied by high solubility is indicative of the weak associative forces in the starch granules in these varieties. This may be attributed to the damage caused by milling to the starch granules. This implies that starch from these varieties can be hydrolyzed easily to produce sugars without using energy as compared to varieties with strong associative forces (Moorthy and Ramanujam 1986).

\section{Water absorption capacity (WAC) of cassava varieties}

The water absorption capacity of cassava influences the industrial application of the flour such as its use in the baking. The baking quality of flours is a function of water absorption capacity (Shittu et al. 2008). All the cassava varieties studied showed varied water absorption capacities for all the processing methods, both at $27^{\circ} \mathrm{C}$ and $70^{\circ} \mathrm{C}$. WAC was higher at $70^{\circ} \mathrm{C}$ than $27^{\circ} \mathrm{C}$ for all the cassava varieties for all the processing methods. It ranged from 125.22 to $230.55 \%$ and 150.21 to $242.14 \%$ at $27^{\circ} \mathrm{C}$ and $70^{\circ} \mathrm{C}$ respectively (Table 1). The observed differences in WAC of the various cassava samples might be due to various factors such as particle size of the starches, amylose/amylopectin ratio and molecular structure. The larger the granular size, the greater the WAC, while the higher the amylose levels, the lower the WAC of starches (Akalu et al. 1998). The variations in WAC values also indicate differences in the degree of engagement to form hydrogen and covalent bonds between starch chains and the degree of availability of water binding sites among the starches (Hoover and Sosulski 1986).

\section{Viscoelastic properties of cassava varieties}

The viscoelastic properties present useful information on the hot and cold paste of starch-based foods. When starch based foods are heated in an aqueous environment, they undergo a series of changes known as gelatinization and pasting (Maziya-Dixon $e t$ al. 2005). The ability of starch to swell and give a viscous paste when an aqueous suspension of the starch granules are heated above the gelatinization temperature is one of the most important functional properties of starch (Afoakwa and Sefa-Dedeh 2002). Gelatinization and pasting are two of the most important properties that influence quality and aesthetic considerations in the food industry, since they affect texture and digestibility as well as the end use of starchy foods (Maziya-Dixon et al. 2005). Table 3 gives the viscoelastic properties of all the cassava varieties studied for all the processing methods. 
Table 3: Viscoelastic characterization of cassava flour

\begin{tabular}{|c|c|c|c|c|c|c|c|c|c|}
\hline $\begin{array}{c}\text { Processing } \\
\text { method }\end{array}$ & Variety & $\begin{array}{c}\text { Pasting } \\
\text { temperature } \\
\left({ }^{\circ} \mathrm{C}\right)\end{array}$ & $\begin{array}{c}\text { Peak } \\
\text { viscosity } \\
\text { (BU) }\end{array}$ & $\begin{array}{c}\text { Viscosity } \\
\text { at } 95^{\circ} \mathrm{C} \\
\text { (BU) }\end{array}$ & $\begin{array}{c}\text { Viscosity } \\
\text { at } \\
9^{\circ} \mathrm{C}- \\
\text { Hold } \\
\text { (BU) }\end{array}$ & $\begin{array}{c}\text { Viscosity } \\
\text { at } \\
\mathbf{5 0}^{\circ} \mathbf{C} \\
(\mathbf{B U})\end{array}$ & $\begin{array}{c}\text { Viscosity } \\
\text { at } \\
\mathbf{5 0}^{\circ} \mathrm{C}- \\
\text { Hold } \\
\text { (BU) }\end{array}$ & $\begin{array}{l}\text { Breakdown } \\
\text { (BU) }\end{array}$ & $\begin{array}{c}\text { Setback } \\
\text { (BU) }\end{array}$ \\
\hline \multirow[t]{6}{*}{ Chips } & Chila A & 64.2 & 558 & 486 & 248 & 254 & 238 & 309 & 4 \\
\hline & Chila B & 64.6 & 402 & 394 & 166 & 126 & 106 & 236 & -38 \\
\hline & Mweulu & 63.5 & 563 & 485 & 237 & 211 & 193 & 327 & -25 \\
\hline & Bangweulu & 65.9 & 593 & 412 & 242 & 205 & 188 & 352 & -36 \\
\hline & Tanganyika & 67.6 & 595 & 592 & 317 & 218 & 219 & 277 & -100 \\
\hline & Kampolombo & 66.6 & 490 & 467 & 219 & 196 & 171 & 271 & -23 \\
\hline \multirow[t]{6}{*}{ Grating } & Chila A & 64.7 & 606 & 600 & 332 & 185 & 177 & 275 & -145 \\
\hline & Chila B & 66.2 & 581 & 573 & 282 & 185 & 162 & 298 & -98 \\
\hline & Mweulu & 64.5 & 622 & 605 & 289 & 203 & 190 & 332 & -86 \\
\hline & Bangweulu & 66.7 & 550 & 538 & 252 & 245 & 218 & 298 & -6 \\
\hline & Tanganyika & 64.3 & 645 & 539 & 261 & 257 & 224 & 383 & -5 \\
\hline & Kampolombo & 64.8 & 568 & 396 & 222 & 100 & 87 & 346 & -121 \\
\hline \multirow[t]{6}{*}{ Soaking } & Chila A & 66.0 & 493 & 428 & 155 & 150 & 135 & 338 & -5 \\
\hline & Chila B & 66.9 & 563 & 485 & 237 & 211 & 193 & 327 & -25 \\
\hline & Mweulu & 63.9 & 684 & 683 & 359 & 261 & 238 & 324 & -98 \\
\hline & Bangweulu & 66.7 & 520 & 348 & 165 & 146 & 130 & 355 & -19 \\
\hline & Tanganyika & 66.4 & 569 & 559 & 301 & 220 & 204 & 267 & -81 \\
\hline & Kampolombo & 50.3 & 588 & 552 & 270 & 189 & 177 & 317 & -80 \\
\hline
\end{tabular}

\section{Pasting temperature}

The pasting temperature is the temperature at which irreversible swelling of the starch granules occurs leading to the formation of a viscous paste in a aqueous solution and it is the temperature at which the first detectable viscosity is measured by the amylograph (Afoakwa et al. 2010b) and it is characterized by an initial change in the viscosity due to the swelling properties of the starch granules. Pasting temperature gives an indication of the gelatinization time during processing. The pasting temperature, which is a reflection of the swelling of the starch granules, is affected by the starch concentration (Rasper 1980). Generally, a high starch concentration leads to a low pasting temperature and the presence of monosaccharides and oligosaccharides have been reported to lead to an upward shift of pasting temperature (Colonna et al. 1992).

The pasting temperature ranged from $50.3^{\circ} \mathrm{C}$ to $66.9^{\circ} \mathrm{C}$ with soaked Kampolombo recording the least whiles soaked Chila $\mathrm{B}$ recorded the highest (Table 3). With the exception of soaked Kampolombo which recorded a pasting temperature of $50.3^{\circ} \mathrm{C}$, the rest of the cassava samples for all the processing methods had pasting temperature above $60^{\circ} \mathrm{C}$. Pasting temperature has been reported to relate to water binding capacity (Maziya-Dixon et al. 2005). A higher pasting temperature implies higher water binding capacity, higher gelatinization, and lower swelling property of starch due to a high degree of association between starch granules (Emiola and Delarosa 1981; Numfor et al. 1996). Again, pasting temperature has been reported to provide an indication of the minimum temperature required for sample cooking, energy cost involved and other components stability (Ikegwu et al. 2009) and foods with lower pasting temperatures are generally considered to be easier to cook (Afoakwa et al. 2010a).

The high pasting temperature observed for all the samples suggest that these cassava flours processed by any of these processing methods would have relatively high cooking temperature and time profile compared to soaked Kampolombo which recorded the least pasting temperature. Even though soaked Kampolombo flour, which recorded the least pasting temperature, could be considered easier to cook, lower pasting temperatures are also associated with low paste stability, which is usually considered to be an undesirable property. Low pasting temperature and low paste stability indicate that fewer associative forces and cross- links are present within the starch granule (Afoakwa and Sefa-Dedeh 2002).

\section{Peak viscosity}

Peak viscosity, which is the maximum viscosity developed during or soon after the heating process (Ikegwu et al. 2009) is linked to the ease of cooking of the samples being analyzed (Afoakwa et al. 2010b). It is measured as the highest value of viscosity attained by the paste during the heating cycle $\left(25-95^{\circ} \mathrm{C}\right)$ and it reflects the ability of starch to swell freely before their physical breakdown (Sanni et al. 2004). Peak viscosities of all the cassava varieties for all the processing methods are shown in Table 3 . Soaked Mweulu gave the highest peak viscosity of 684 BU whiles Chila B chips recorded the least peak viscosity of 402 BU. Both varietal differences and processing method significantly influenced the peak viscosity of the cassava flour samples ( $\mathrm{p}<0.05)$. Grating increased 
the peak viscosity of the flour samples than chips and soaking. With the exception of Kampolombo and Chila B chips as well as soaked Chila A which recorded peak viscosities of $490 \mathrm{BU}, 402 \mathrm{BU}$ and $493 \mathrm{BU}$ respectively, the rest of the cassava varieties for all the processing methods recorded peak viscosities above $500 \mathrm{BU}$.

Peak viscosity has been reported to be closely associated with the degree of starch damage and high starch damage results in high peak viscosity (Sanni et al. 2001). Again, variation in the peak viscosity might be as a result of the amylose contents of the starches (Ikegwu et al. 2009) which is influenced by the processing method. Oguntunde (1987) reported that the associative bonding of the amylose fraction is responsible for the structure and pasting behaviour of starch granule. The viscosity or more correctly the consistency of a cooked starch paste simply reflects the resistance to stirring of the swollen mass gel particles. Peak viscosity is often correlated with final product quality, and also provides an indication of the viscous load likely to be encountered during mixing (Maziya-Dixon et al. 2005).

High peak viscosity (>500 BU) is an indication of high starch content which also relate to water binding capacity of starch (Osungbaro 1990). Rosenthal et al. (1974) suggested that high peak viscosity contributes to good texture of paste, which basically depends on high viscosity and moderately high gel strength. The relatively high peak viscosity ( $>500 \mathrm{BU})$ exhibited by most of the cassava varieties in this study is indicative that flours from these cassava varieties processed either by chipping, grating or soaking may be suitable for products requiring high gel strength and elasticity.

\section{Heating cycle (viscosity at $95^{\circ} \mathrm{C}$ and viscosity at $95^{\circ} \mathrm{C}$-hold)}

The viscosity at $95^{\circ} \mathrm{C}$ measures the ease of cooking of the sample by the amylograph. A low viscosity at $95^{\circ} \mathrm{C}$ is reported to be indicative of the ease of cooking of the sample (Afoakwa et al. 2010b). Viscosity at $95^{\circ} \mathrm{C}$ ranged from $348 \mathrm{BU}$ to $683 \mathrm{BU}$ for all the cassava varieties and processing methods. With the exception of Kampolombo, all the grated flour samples had relatively high viscosities of above $500 \mathrm{BU}$ at $95^{\circ} \mathrm{C}$. The relatively high viscosities $(>500 \mathrm{BU})$ of these cassava flour samples at $95^{\circ} \mathrm{C}$ suggest that these grated cassava flour would be relatively easier to cook compared to the soaked and chipped samples.

The viscosity attained by the sample after holding the temperature constant at $95^{\circ} \mathrm{C}$ for 30 min indicates the ease of breakdown of the cooked paste. This illustrates the stability of the paste during cooking. During the hold period there is further disruption of the starch granules and amylose molecules generally leach out into the solution and align in the direction of the shear (Maziya-Dixon et al. 2005). Viscosity at $95^{\circ} \mathrm{C}$-hold was relatively high for all grated cassava flour samples. Soaked Mweulu flour however had the highest viscosity at $95^{\circ} \mathrm{C}$-hold of $359 \mathrm{BU}$ whiles soaked Chila A was observed to produce the least viscosity of 155 $\mathrm{BU}$ at $95^{\circ} \mathrm{C}$-hold. A gradual decrease of the paste viscosity during the hold period indicates thermal breakdown of starch and, thus, may be considered a measure of stability. According to Maziya-Dixon et al. (2005) this period is sometimes called shear thinning, holding strength, hot paste viscosity, or trough, due to the accompanied breakdown in viscosity. Large values indicate little breakdown of sample starches. With the exception of soaked Chila A and Bangweulu as well as Chila B chips which recorded viscosities below $200 \mathrm{BU}$, the rest of the cassava flour samples recorded values above $200 \mathrm{BU}$ for all the processing methods. This suggest that these cassava flour samples for all the processing methods with high viscosity ( $>200 \mathrm{BU})$ at $95^{\circ} \mathrm{C}$-hold experienced little breakdown in starch, thus, may be considered stable.

\section{Cooling cycle (viscosity at $50^{\circ} \mathrm{C}$ and viscosity at $50^{\circ} \mathrm{C}$-hold)}

Viscosity at $50^{\circ} \mathrm{C}$ reflects the retrogradation tendency of the cooked paste (Afoakwa et al. 2010b) and are most significant with respect to the eating quality of foods as they reflect the eating consistency of the product. An increased retrogradation property of the paste can be attributed to the association of the starch molecules caused by the strong tendency for hydrogen bond formation between hydroxyl groups on adjacent molecules (Afoakwa and Sefa-Dedeh 2002). The three processing methods produced varied viscosities at $50^{\circ} \mathrm{C}$ for the various cassava flour samples. Viscosity at $50^{\circ} \mathrm{C}$ ranged from $100-261 \mathrm{BU}$ for all the cassava varieties and processing methods. There was significant difference $(\mathrm{p}<0.05)$ in viscosity at $50^{\circ} \mathrm{C}$ among the cassava varieties and processing methods (Table 3).

The viscosity at $50^{\circ} \mathrm{C}$-hold measures the stability of the paste as it might be used in products. It was observed that the viscosity of the samples at $50^{\circ} \mathrm{C}$-hold was lower than the viscosity at $50^{\circ} \mathrm{C}$ for all the samples. Grated Kampolombo however recorded the least viscosity of $87 \mathrm{BU}$ at $50^{\circ} \mathrm{C}$-hold. There was significant $(\mathrm{p}<0.05)$ difference in the viscosities at $50^{\circ} \mathrm{C}$-hold for all the cassava varieties and processing methods.

\section{Breakdown viscosity and setback}

Breakdown viscosity is the measure of the tendency of swollen starch granules to rupture when held at high temperatures and continuous shearing (Patindol et al. 2005) and it is indicative of the stability of the starch on heating (Afoakwa et al. 2010a). High breakdown viscosity suggests that the starches are unstable during heating. This means that such starches cannot be used for products where starch stability is required at very high temperatures, because they will breakdown. Breakdown viscosity ranged from $236 \mathrm{BU}$ (Chila B chip) to 383 BU (grated Tanganyika) (Table 3). Significant differences $(p<0.05)$ existed amongst the varieties and processing methods. Aryee et al. (2006) reported that high breakdown viscosity is an indication of very weak cross-linking within the starch granules.

Setback is the measure of the paste hardening on cooling (Afoakwa et al. 2012) and a stage where retrogradation or reordering of starch molecules occurs (Maziya-Dixon et al. 2005). Setback has been correlated with texture of various products and Maziya-Dixon et al. (2005) observed that high setback is associated with syneresis, or weeping, during freeze/thaw cycles. Adeyemi and Idowu (1990) also reported that a high setback value indicates lower retrogradation tendency during cooling and the lower the staling rate of products made from such flours. Oduro et al. (2000) explained that high setback value is useful if the flour is to be used in domestic products such as $f u f u$, which requires high viscosity and paste stability at low temperature. Chila A chip registered the highest setback value of $4 \mathrm{BU}$ which was significantly different $(\mathrm{p}<0.05)$ from the other studied varieties and processing methods. This indicates that flour from Chila A chip recovered most of its amylose content during cooling than all the other studied flour samples. However, grating Chila A resulted in a very low setback value as it recorded the least setback value of -145 BU. Grated Kampolombo and Tanganyika chips also recorded low setback values of $-121 \mathrm{BU}$ and $-100 \mathrm{BU}$ respectively which indicates that these flour gives a 
non-cohesive paste (Kim et al. 1995). This means that such flours cannot be used for products in which starch stability is required at low temperatures, such as adhesives, fillings and products that require refrigeration.

\section{Starch pasting characteristics of cassava varieties}

Figure 1 show a typical pasting profile curve (amylogram) generated from Brabender Viscoamylograph. Region A represents the beginning of gelatinization (pasting temperature). Regions B, C and D represent the peak viscosity, viscosity at $95^{\circ} \mathrm{C}$, and viscosity at $95^{\circ} \mathrm{C}$-hold respectively. Regions $\mathrm{E}$ and $\mathrm{F}$ show viscosity at $50^{\circ} \mathrm{C}$ and viscosity at $50^{\circ} \mathrm{C}$-hold respectively whiles region B-D represent breakdown viscosity and E-D shows setback. Figures 2, 3 and 4 show amylogram generated from Brabender Viscoamylograph for the cassava varieties processed by chips, grating and soaking respectively. A closer look at the amylograms for all the studied cassava varieties (Figures 2-4) revealed that the viscosity of all the cassava varieties increased to a peak (peak viscosity) with soaked Mweulu flour recording the highest peak viscosity of $684 \mathrm{BU}$ whiles flour of Chila B chip recorded the least (402 BU). The viscosity of all the cassava paste decreased during the heating cycle $\left(95^{\circ} \mathrm{C}\right.$ and $95^{\circ} \mathrm{C}$-hold $)$ for all processing methods.

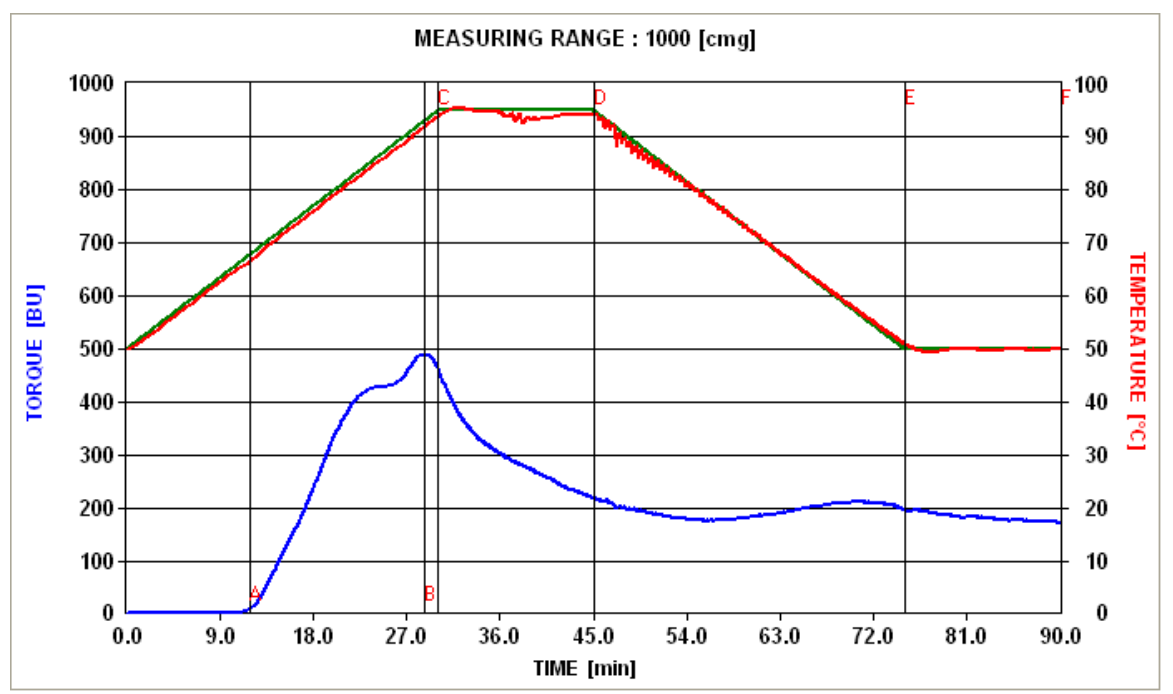

Figure 1: A typical pasting profile curve (amylogram) from the Brabender Viscoamylograph

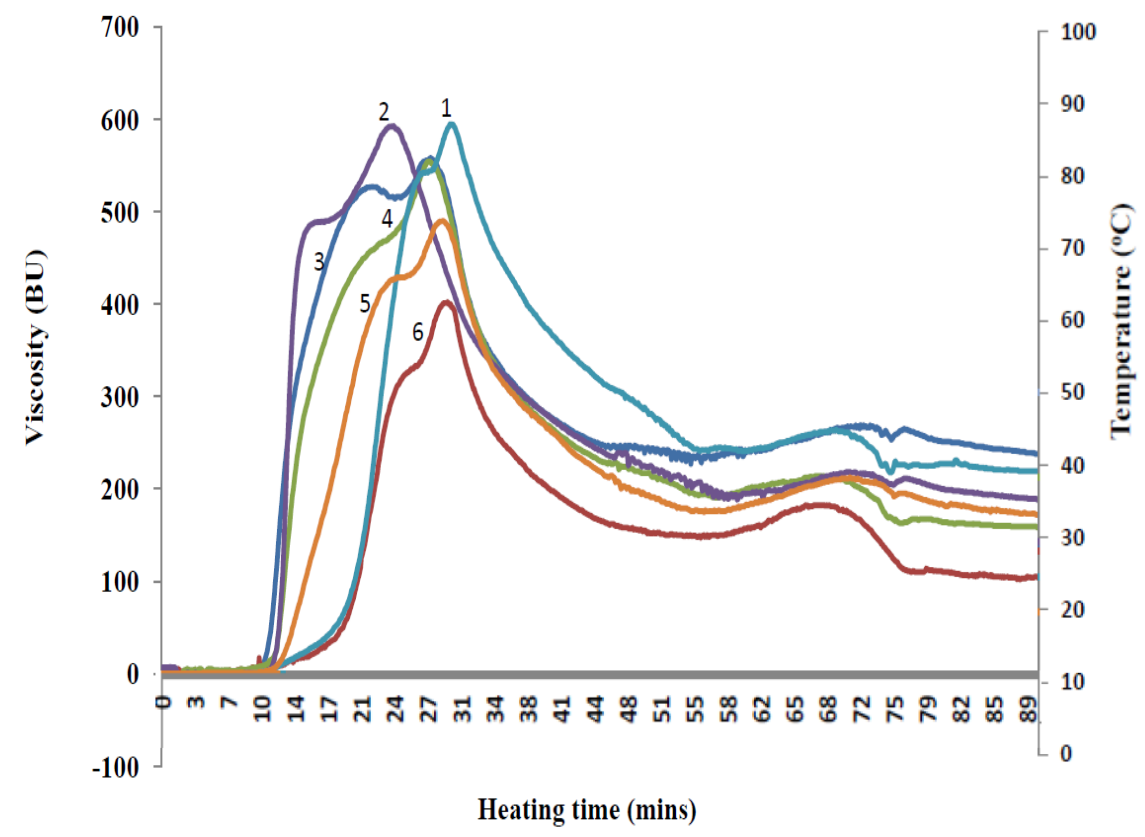

KEY: 1- Tanganyika; 2- Bangweulu; 3- Chila A; 4- Mweulu; 5- Kampolombo; 6- Chila B

Figure 2: Amylogram showing the pasting characteristic profiles of the studied cassava varieties processed by chipping 


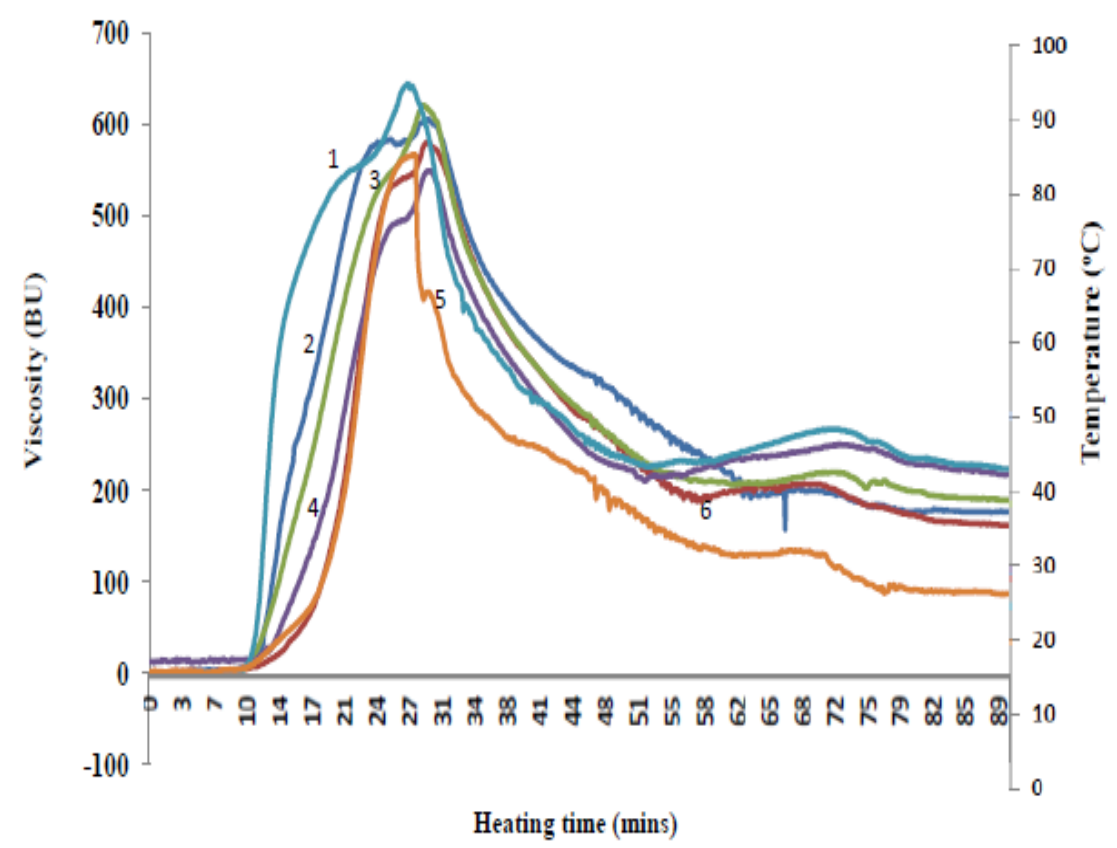

KEY: 1- Tanganyika; 2- Chila A; 3- Mweulu; 4- Bangweulu; 5- Kampolombo; 6- Chila B

Figure 3: Amylogram showing the pasting characteristic profiles of the studied cassava varieties processed by grating

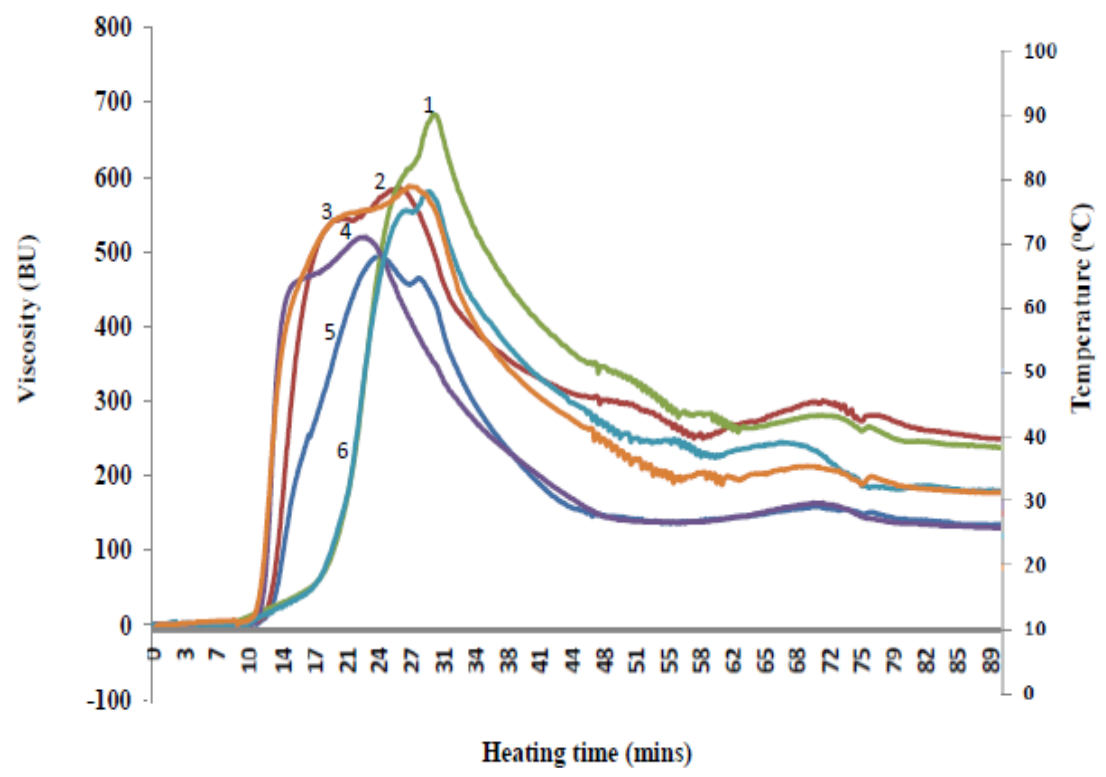

KEY: 1- Mweulu; 2- Chila B; 3- Kampolombo; 4- Bangweulu; 5- Chila A; 6- Tanganyika

Figure 4: Amylogram showing the pasting characteristic profiles of the studied cassava varieties processed by soaking

During the cooling cycle, from 95 to $50^{\circ} \mathrm{C}$, the viscosity of the pastes observed for all the cassava varieties (with the exception of flour of Chila A chip) decreased considerably as compared to the viscosity of the pastes observed during the heating cycle. The increase in the viscosity of the paste of the flour of Chila A chip sample during the cooling cycle could probably be due to the gelatinization and consequent swelling of the starch granules of Chila A chip starches as the elements present in the hot paste (swollen granules, fragments of swollen granules, colloidally and molecularly dispersed starch molecules) begin to associate or retrograde as the temperature of the paste decreases. The amylograms also revealed that the viscosity of the samples at $50^{\circ} \mathrm{C}$-hold was lower than the viscosity at $50^{\circ} \mathrm{C}$ for all the samples. A close examination of the pasting characteristics revealed that soaked Mweulu showed higher pasting characteristics. 


\section{CONCLUSION}

The physico-functional properties varied with all the cassava varieties and processing methods. Soaking and grating reduced $\mathrm{pH}$ of the flour with consequential increase in titratable acidity. Grating and soaking cassava tubers for 48 hours could be used to produce products that require sourness as a quality attribute. Soaked Kampolombo had the highest L*-value of 78.40 suggesting that the soaked Kampolombo cassava sample was whiter than the rest of the samples. Grating cassava as well as soaking cassava tubers for 48 hours reduced the swelling power and solubility of the flour samples. Soaked Chila B flour recorded the highest pasting temperature of $66.9^{\circ} \mathrm{C}$ suggesting that the flour would have high cooking temperature and time profile. Soaked Mweulu flour sample recorded the highest peak viscosity $(684 \mathrm{BU})$, viscosity at $95^{\circ} \mathrm{C}(683 \mathrm{BU})$ and viscosity at $95^{\circ} \mathrm{C}$-hold $(359 \mathrm{BU})$. This suggests that flour from soaked Mweulu might be suitable for products requiring high gel strength and elasticity, easier to cook and also more stable during cooking. Chila A chip flour registered the highest setback value of 4 BU suggesting that Chila A chip flour would be used for products which requires high viscosity and paste stability at low temperature. Grated Kampolombo flour and Tanganyika chip flour also recorded low setback values of $-121 \mathrm{BU}$ and $-100 \mathrm{BU}$ respectively suggesting that these flours cannot be used for products in which starch stability is required at low temperatures, such as adhesives, fillings and products that require refrigeration.

\section{REFERENCES}

Abu, J.O., Badifu G.I.O, and Akpapunan M.A. 2006. Effect of Crude palm-oil inclusion on some physico-chemical properties of gari, a fermented cassava food product. Journal of Food Science and Technology 24: 73 - 79.

Adeyemi, I. A. and Idowu, M. A. 1990. The evaluation of pregelatinised maize flour in the development of Massai, a baked product. Nigeria Food Journal 8: 63-73.

Adeyemi, I. A., and Omolayo, O. 1984. Utilization of cocoyam flour and starch for biscuit and cake making. Nigeria Journal of Science 18: 34-37.

Afoakwa, E. O., \& Sefa-Dedeh, S. 2002. Viscoelastic properties and changes in pasting characteristics of trifoliate yam (Dioscorea dumetorum) starch after harvest. Food Chemistry 77: 203-208.

Afoakwa, E. O., Adjonu, R., and Asomaning, J. 2010a Viscoelastic properties and pasting characteristics of fermented maize: Influence of the addition of malted cereals. International Journal of Food Science Technology 45: 380-386.

Afoakwa, E. O., Kongor, E. J., Annor, G. A., \& Adjonu, R. 2010b. Acidification and starch behaviour during co-fermentation of cassava (Manihot esculenta Crantz) and soybean (Glycine max Merr) into gari, an African fermented food. International Journal of Food Science and Nutrition, 61: 449-462.

Afoakwa, E. O., Budu, A. S., Asiedu, C., Chiwona-Karltun, L. and Nyirenda, D. B. 2012. Viscoelastic properties and physicofunctional characterization of six high yielding cassava mosaic disease-resistant cassava (Manihot esculenta Crantz) genotypes. Journal of Nutrition and Food Science 2: 129-137.

Akalu, G., Tufvesson, F., Jonsson, C., and Nair, B.M.. 1998. Physicochemical characteristics and functional properties of starch and dietary fibre in grass pea seeds. Starch/Stärke 50: 374-382

Amani N. G, Kamenan A, Rolland-Sabaté A and Colonna P. 2005. Stability of yam starch gels during processing. African Journal of Biotechnology. 4: 94-101.

Apea-Bah F.B., Oduro I, Ellis W.O. and Safo- Kantanka O.2009. Principal components analysis and age at harvest effect on quality of gari from four elite cassava varieties in Ghana. African Journal of Biotechnology 8: 1943 - 1949.

Aryee, F. N. A., Oduro, I., Ellis, W. O., and Afuakwa, J. J. 2006. The physicochemical properties of flour samples from the roots of 31 varieties of cassava. Food Control. 17: 916-922.

Assanvo J.B. 2008. Enquêtes de production et de consommation de l'attiéké traditionnel ivoirien et caractéristique organoleptique d'attiéké issus de quatre variétés de manioc (IAC, Bonoua, Olekanga et TMS 4 (2) 1425). Thèse unique de Doctorat en Biochimie et Sciences des Aliments, Université de Cocody- Abidjan, Côte d'Ivoire. pp 195.

Bokanga M. 2001. Cassava: Post-harvest operations. International Institute of Tropical Agriculture (IITA), Ibadan, Nigeria, 220p.

Champagne, E. T., Bett, K. L., Vinyard, B. T., Mcclung, A. M., and Barton, F. E. (1999). Correlation between cooked rice texture and rapid visco analyzer measurements. Cereal Chemistry 76: 764-771.

Clydesdale, F.M. 1984. The Influence of colour on the sensory perception and food choices In Developments in Food Colours-2 edited by John Walford, Elsevier applied Science Publishers. London and New York.

Colonna, P., Leloup, V., and Buleon, A. 1992. Limiting factors of starch hydrolysis. European Journal of Clinical Nutrition. 46: $517-$ 532.

Defloor, I., Leijskens, R., Bokanga, M., and Delcour, J. A. 1994. Impact of genotype and crop age on the bread making and physicochemical properties of flour produced from cassava (Manihot esculenta Crantz) planted in the dry season. Journal of the Science of Food and Agriculture 66: 193-202.

Emiola, L., and Delarosa, L. C. 1981. Physicochemical characteristics of yam starches. Journal of Food Biochemistry 5: 115-130.

Food and Agriculture Organization 2008. Le manioc pour la sécurité alimentaire et énergétique - Investir dans la recherché pour en accroître les rendements et les utilisations. FAO salle de presse (éditeur), Juillet 2008 Rome, Italie. Retrieved on 12/05/2012 http://www.fao.org/newsroom/FR/news/. 
Gujska, E., Reinhard, W.D., and Khan, R. 1994. Physicochemical properties of field pea, pinto and navy bean starches. Journal of Food Science 59: 634-636.

Hashim M., Moorthy, S. N. Mitchell, J. R. Hill, S. E., Linfoot, K. J. and Blanshard J. M. V. 1992: The effect of low levels of antioxidants on the swelling and solubility of cassava starch. Starch/Stärke 44: 471-475.

Hoover, R., and Sosulski, F.1986. Effect of cross linking on functional properties of legume starches. Starch/Stärke, 38:149-155.

Ikegwu, O. J., Nwobasi, V. N., Odoh, M. O., and Oledinma, N. U. 2009. Evaluation of the pasting and some functional properties of starch isolated from some improved cassava varieties in Nigeria. African Journal of Biotechnology. 8: 2310-2315.

Iwe, M. O., Wolters, T., Gort, G., Stolp, W., and Van Zuilichem, D. J. 1999. Behaviour of gelatinization and viscosity in soy-sweet potato mixtures by single-screw extrusion: A response surface analysis. Journal of Food Engineering. 38 (3): $369-379$.

Kawano, K. 2003. Thirty years of cassava breeding for productivity: biological and social factors for success. Crop Science 43: $1325-$ 1335.

Kim, Y. S., Wiesenborn, D. P., Orr, P. H., and Grant, L. A. 1995. Screening potato starch for novel properties using differential scanning calorimetry. Journal of Food Science 60: 1060-1065.

Lei, V., Amoa-Awua, W.K.A. and Brimer, L. 1999. Ability to degrade cyanogenic glycosides using Lactobacillus plantarum strains from spontanous cassava fermentation and other microorganisms. International Journal of Food Microbiology 53: 169. 184.

Maziya-Dixon, B., Adebowale, A. A., Onabanjo, O. O. and Dixon, A. G. O. 2005. Effect of variety and drying methods on physicochemical properties of high quality cassava flour from yellow cassava roots. African Crop Science Conference Proceedings, Vol. 7. pp. 635-641.

Maziya-Dixon, B., Dixon, A. G. O. and Adebowale, A. A. 2007. Targeting different end uses of cassava: Genotypic variations for cyanogenic potentials and pasting properties. International Journal of Food Science and Technology. 42: 969-976.

Mégnanou, R. M., Kouassi, S. K., Akpa, E. E., Djedji, C. and Bony, N. 2009. Physicochemical and biochemical characteristics of improved cassava varieties in Cote d'Ivoire. Journal of Animal and Plant Science 5: 507-514.

Moorthy, S. 1985. Effect of different types of surfactants on cassava starch properties. Journal of Agriculture and Food Chemistry 35: $1227-1232$.

Moorthy, S. N., and Ramanujam, T. 1986: Variation in properties of starch in cassava varieties in relation to age of the crop. Starch/ Stärke, 38: 58-61.

Numfor, F. A., Walter, W. M., and Schwartz, S. J. 1996. Effect of emulsifiers on the physical properties of native and fermented cassava starches. Journal of Agriculture and Food Chemistry 44: 2595 - 2599.

Oduro, I., Ellis, W. O., Dziedzoave, N. T. and Nimako Y. K. 2000. Quality of gari from selected processing zones in Ghana. Food Control 11: 297-303.

Oguntunde, A. O. 1987. Starch modification for food application: review. Nigeria Food Journa; 5: 102-107.

Okigbo, B. N. 1980. Nutritional implications of projects giving high priority to the production of staples of low nutritive quality. In the case for cassava (Manihot esculenta, Crantz) in the humid tropics of West Africa. Food and Nutrition Bulletin 2: 1-10.

Osungbaro, T. O. 1990. Effect of differences in varieties and dry milling of maize on the textural characteristics of Ogi (fermented maize porridge) and Agidi (fermented maize meal). Journal of the Science of Food and Agriculture 52: 1-12.

Patindol, J., Wang, Y. J., and Jane, J. L. 2005. Structure-functionality changes in starch following rough rice storage. Starch-Stärke, 57: 197-207.

Rasper, V. 1980. Theoretical aspests of amylographology. In: The amylograph handbook. Shuey, W. C., Tipples, E. E. (Eds.). St Paul, $\mathrm{MN}$ : America Association of Cereal Chemists.

Riley, C.K., Wheatly, A.O., and Asemota, H.N. 2006. Physicochemical characterization of starches from Jamaican yams (Dioscorea spp.): Potential for pharmaceutical exploitations. European Journal of Scientific Research 15 (2): 207-219.

Rosenthal, F. R. T., Nakamura, T., Espindola, A. M. C., and Jochimek, M. R. 1974. Structure of starch granules. Die Starke, $26: 50-55$.

Sanni, L. O., Ikuomola, D. P. and Sanni, S. A. 2001. Effect of length of fermentation and varieties on the qualities of sweet potato gari. Proceedings of 8th triennial Symposium of the International Society for Tropical Root Crops. Africa Branch (ISTRCAB), Ed. M.O. Akoroda, IITA, Ibadan, Nigeria, 12-16 November 2001, pp. 208-211.

Sanni, L. O., Kosoko, S. B., Adebowale, A. A. and Adeoye, R. J. 2004. The Influence of palm oil and chemical modification on the pasting and sensory properties of fufu flour. International Journal of Food Properties 7: 229-237.

Sasaki, T., and Matsuki, J. 1998. Effect of wheat starch structure on swelling power. Cereal Chemistry. 75: 525-529.

Sefa-Dedeh, S., Cornelius, B., Amoa-Awua, W., Sakyi-Dawson, E., and Afoakwa, E. O. 2004. The microflora of fermented nixtamalized corn. International Journal of Food Microbiology. 96: 97-102. 
Shittu, T. A., Sanni, L.O., Awonorin, S. O., Maziya-Dixon, B. and Dixon, A. 2007. Effect of genotype on the flour making properties of some CMD resistant varieties of cassava. Food Chem. 101, 1634-1643.

Shujun, W., Hongyan, L., Wenyuan, G, Haixia, C., Jiugao, Y., and Peigen, X. 2006. Characterization of new starches separated from different Chinese yam (Dioscorea opposite Thunb.). Food Chemistry 99: 30-37.

Srichuwong, S., Sunarti, T.C., Mishima, T., N. and Hisamatsu, M. 2005. Starches from different botanical sources I: Contribution of amylopectin fine structure to thermal properties and enzyme digestibility. Carbohydrate Polymers 60: 529-538.

Tang, H., Mitsunaga, T., and Kawamura, Y. 2005. Functionality of starch granules in milling fractions of normal wheat grain. Carbohydrate Polymers 59:11-17.

Vamos-Vigyazo, L. 1981. Polyphenoloxidase and peroxidase in fruits and vegetables. CRC Critical Review of Food Science and Nutrition 15: 49- 52.

Yuan, Y., Zhang, L., Dai, Y., and Yu, J. 2007. Physicochemical properties of starch obtained from Dioscorea nipponica Makino comparison with other tuber starches. Journal of Food Engineering. 82: 436-442. 